\title{
The Free Trade Debate, Economic Recession and the Global South since 2000AD
}

\author{
Nwachukwu J. Obiakor \& Abuoma C. Agajelu \\ http://dx.doi./org/10.4314/ujah.v19i1.3
}

\begin{abstract}
The end of the Cold War, which came on the heels of the disintegration of the Soviet Union and the near-collapse of the Soviet-styled communist ideology, paved the way for globalization and the entrenchment of a Western-styled economic system hinged on free enterprises. Free enterprises encourage such liberal economic programmes as private initiative and entrepreneurship, accumulation of capital, de-regulation, competition, and trade liberalization, among others. Most developing countries, without much choice, got integrated into this global capitalist system. How they fare as regards economic growth and development is determined by an objective research and interpretation of available data on their economic performance since the trend of "free trade" absorbed them in the global capitalism. The debate on the credibility of "free trade" as a determinant of mutual economic growth and development has been prevalent in international political economy discourse since the $18^{\text {th }}$ century. The credibility of "free trade" has been called into question, especially its effects on the countries of the global South or the developing economies. This study assesses the debate on free trade over the years and how this trend affects the countries of the South in the $21^{\text {st }}$ century economic recession. Most of the scholars and experts of the developing world extraction vehemently kick against the premature integration of the developing economies into the already established western capitalism. They blame the adverse effects of the recession on the South on this unequal relationship. This study also presents some of their arguments. The work makes use of diverse secondary and tertiary
\end{abstract}


sources and the thematic historical approach in the interpretation and discussion of the accounts presented.

Key words: Free trade, globalization, economic recession, and global South

\section{Introduction}

The concept of free trade in political economy emanated from the influence of the $18^{\text {th }}$ century writings of the philosopher Adam Smith. Smith explicitly advocated for free trade and popularized the concept of Laissez-faire (a doctrine opposing governmental interference in economic affairs beyond the minimum necessary for the maintenance of peace and property rights) in economics. He expressed the uncertainties of monopoly and regulation of economic activities in his book when he stated inter alia:

That this monopoly of the home market frequently gives great encouragement to that particular species of industry which enjoys it, and frequently turns towards that employment a greater share both the labour and stock of the society than would otherwise have gone to it, cannot be doubted. But whether it tends either to increase the general industry of the society, or to give it the most advantageous direction, is not, perhaps, altogether so evident. Adam Smith (1776).

Smith (1776) further expressed his stand against regulation of economic activities when he stated that "no regulation of commerce can increase the quantity of industry in any society beyond what its capital can maintain". With these notions of Adam Smith's, the contemporary proWest economists and the governments of capitalist countries arm themselves to encourage bilateral and multilateral Free Trade Agreements (FTAs) under established institutions as the General Agreement on Tariffs and Trade (GATT), which was later replaced by the World Trade Organisation (WTO).

In line with what may be regarded as "Smithism", GATT was a post World War II economic reconstruction measure which aims at 
liberalising trade as a means of ensuring mutual economic growth and development of nations which are signatories to it. It subsequently proved to be the most effective instrument of world trade liberalization, playing a major role in the massive expansion of world trade in the second half of the $20^{\text {th }}$ century. By the time GATT was replaced by the World Trade Organisation (WTO) in 1995, 125 nations were signatories to its agreements. These agreements had become a code of conduct governing 90 percent of world trade.

Under the watch of GATT, trade agreements were also concluded on sub-regional and continental levels. Popular ones are European Free Trade Association (EFTA), which is a group of four countries - Iceland, Liechtenstein, Norway, and Switzerland - in Northern Europe sub-region. The European Economic Community (EEC; now part of the European Union) encourages free trade at the continental level. There is also the North American Free Trade Agreement (NAFTA), a trade pact signed in 1992 that would gradually eliminate most tariffs and other trade barriers on products and services passing between the United States, Canada, and Mexico. There is the Association of South East Asian Nations (ASEAN) in Asia, which originated in 1961 as the Association of South East Asia (ASA) founded by the Philippines, Thailand, and the Federation of Malaya (now part of Malaysia). This was also a sub-regional economic association aimed at accelerating free trade among member nations. Then in the Caribbean world there is the Caribbean Community and Common Market (CARICOM), which was established in 1973 by 12 Caribbean countries as a successor to the Caribbean Free Trade Association (CARIFTA) which was itself founded in 1968. The Economic Community of West African States (ECOWAS) represents West African sub-regional effort at economic integration and establishment of a free trade zone. Founded in 1975, ECOWAS has in its membership at 15 West African states which are both Anglophone and Francophone. That of southern African subregion is called the Southern Africa Development Community (SADC).

As mentioned earlier, these organizations form the platform for multilateral free trade agreements between member countries. There may 
be a mutual agreement that this form of economic liberalisation is desirable for the collective economic development of member countries. Nonetheless, the fact remains that the benefits accruable from this liberalisation is basically because their relations are horizontal. Intense debate emanated as a result of the vertical free trade agreements between the unequal economies of the global North and South. While the agents of trade liberalisation such as the Bretton Woods Institutions and neoclassical counter-revolution market fundamentalist scholars argue that free trade or liberalisation of national markets draws additional domestic and foreign investment and thus increases the rate of capital accumulation, the Marxist and dependency scholars believe that free trade further enriches the industrial economies of the North while impoverishing the southern trade partners through capital flight, brain drain, balance of payment deficits, environmental degradation and so on. In as much as these free trade agreements receded in the present century and nations cowed into protectionism due to the economic recession, they have also intensified since the emergence of China and the "Asian Tigers" as top contenders in what may be regarded as the new scramble for African markets and resources. This study sets out to assess the debates on free trade as it concerns the countries of the global South in this era of economic recession.

\section{Conceptual Clarifications}

This study unavoidably employs some basic concepts, some of which form the main theme of the study. It is, therefore, pertinent to attempt the clarification of some conceptual cobwebs in order to enhance comprehension. The concept of free trade is made popular in recent times by the globalisation of Western capitalism, though it has been as old as the field of political economy. One may ask: what exactly is free trade? David M. Driesen identifies three concepts of free trade which include trade free from discrimination against foreign companies, trade free from coercion, and trade free from restraint, i.e. laissez-faire. Free trade, in a broader sense is defined in the Encyclopaedia Britannica as "a policy by 
which a government does not discriminate against imports or interfere with exports by applying tariffs (to imports) or subsidies (to exports)" (Britannica, 2010). The encyclopaedia goes on to elucidate that a freetrade policy does not necessarily imply, however, that a country abandons all control and taxation of imports and exports. The Investopedia defines it as the unrestricted purchase and sale of goods and services between countries without the imposition of constraints such as tariffs, duties and quotas. Then in the Business Dictionary the concept of free trade is seen as the interchange of goods and services (but not of capital or labour) unhindered by high tariffs, non tariff barriers (such as quotas), and onerous or unilateral requirements or processes.

From the different definitions, it is made clear that free trade is synonymous to trade liberalisation. The parties that are signatory to a free trade agreement keep their borders open and free from restrictions and barriers in order to mutually reap the benefits of market expansion, technology transfer, competitive advantage and so forth. Free trade underscores the capitalist idea of market forces as the determinant of productivity instead of a centrally planned economy. From the definition of the concept of free trade, one can understand the reason why it has elicited intense debate among scholars over the years.

The countries of the global South in political economy are the developing countries which are always at disadvantage in their economic relations with the developed countries of the global North. The MerriamWebster's Dictionary and Thesaurus (Merriam-Webster, 2010) defines the concept of South as the developing nations of the world. How these developing nations fare, in relation with the various Free Trade Agreements (FTAs) they enter with the developed countries of the global North, is the base of discussion in this study. Economic Recession refers to the retrogression in economic activities caused by a number of factors. Recession in economics is a business cycle contraction. It is a general slowdown in economic activities. The online encyclopedia further explains that in economic recession macroeconomic indicators such as GDP (Gross Domestic Product), investment spending, capacity utilisation, household income, business profits, and inflation fall, while 
bankruptcies and the unemployment rate rise. A. C. Prabhakar (2010) infers implicitly that economic recession is marked by financial turmoil, large-scale destruction of wealth and declines in industrial production and global trade. Another view explains that recession in economics is a downward trend in the business cycle characterised by a decline in production and employment, which in turn causes the incomes and spending of household to decline. Julius Shiskin (1975), in a New York Times article suggested some rules for defining a recession - one of which double consecutive quarter drop in GDP. This rule has been reconsidered by some economists who prefer a definition of recession as a $1.5 \%$ rise in unemployment within 12 months. In the U.S, the National Bureau of Economic Research (NBER) which is generally seen as the authority for dating U.S recessions defines an economic recession as "significant decline in economic activity spread across the economy, lasting more than a few months, normally visible in real GDP, real income, employment, industrial production, and wholesale-retail sales."

Economic recession is a gloomy phenomenon that even though not all households and businesses experience actual declines in income, their expectations about the future become less certain during a recession and cause them to delay making large purchases or investments. The question that seeks answer then becomes: do the free trade agreements between the global North and South cause or exacerbate economic recession in the developing economies in the contemporary times?

\section{The Debate on Free Trade in Historical Perspective}

The issue of free trade is one of the most widely debated issues in political economy and has elicited a lot of theories in the field. As is obtainable today, many Western economists and scholars have always advocated for free trade. At the fore front of pro-free trade debate were British economists. This is because liberalism seemed almost without an ideological competitor in Great Britain by the third quarter of the $19^{\text {th }}$ century. Some of the renowned British scholars that advocated for free trade in the early years of industrialisation included David Ricardo, 
Adam Smith, John Stuart Mill among others. The protectionists of the era were mainly from the United States and few European countries. They included Alexander Hamilton, Friedrich List, Jean-Baptiste Colbert and many others. With popularisation of dialectical materialism expounded by Karl Marx, scholars who opposed free trade on the point of view of unequal terms and favour protectionism in a social setting started to emerge. Many of these scholars were of the developing world extraction.

In as much as free trade was favoured in Europe (especially Britain) by the $19^{\text {th }}$ century, the European monarchies favoured protectionist policies in the $17^{\text {th }}$ and $18^{\text {th }}$ centuries in an attempt to increase trade and build their domestic economies at the expense of other nations; these policies, now discredited, became known as mercantilism. Great Britain began to abandon its protective tariffs in the first half of the $19^{\text {th }}$ century after it had achieved industrial preeminence in Europe. However, it seemed as if Great Britain was the only Western economy that stood firm for free trade at the period. A reaction in favour of protection spread throughout other countries of the Western world in the latter part of the $19^{\text {th }}$ century. Germany reportedly adopted a systematically protectionist policy and was soon followed by most other nations.

Shortly after 1860, during the Civil War, the United States raised its duties sharply; the McKinley Tariff Act of 1890 was ultraprotectionist. In the nation, the $19^{\text {th }}$ century was a period of intense debate between the pro free trade liberal democrats and the anti-free trade conservative Republicans. In Britain, Adam Smith was one of the economists and philosophers who were really explicitly vocal about the benefits of free trade and the ills of mercantilism. His monumental work, An Inquiry Into the Nature and Causes of the Wealth of Nations, published in 1776, was one of the earliest attempts to systematically study the historical development of industry and commerce in Europe, as well as a sustained attack on the doctrines of mercantilism.

Adam Smith (1776) wrote of how ancient European nations attempted to horde silver and gold under the belief that accumulation of the precious 
mediums of exchange will allow them to have enough "wherewithal to carry on foreign wars." When the European merchants started to oppose the restrictions on exporting gold and silver, Smith supported their argument and also criticised it to some extent when he stated:

Those arguments were partly solid and partly sophistical. They were solid so far as they asserted that the exportation of gold and silver in trade might frequently be advantageous to the country. They were solid, too, in asserting that no prohibition could prevent their exportation when private people found any advantage in exporting them. (Smith, 1776)

Then Smith found the arguments of the merchants wanting when he stated thus:

...but they were sophistical in supporting that either to preserve or to augment the quantity of those metals required more the attention of government than to preserve or to augment the quantity of any other useful commodities, which the freedom of trade, without any such attention, never fails to supply in the proper quality.(Smith, 1776)

From his analysis of the argument of the merchants against the governments' protectionist attitude to silver and gold, Smith introduced his stand on the issue of free trade. He implied that government intervention is not necessary in trade and will only disrupt its free flow thereby causing the nation unfavourable balance of trade. He asserted, too, that the price regime should determine the balance of trade instead of the government legislation. Adam Smith gave a lot of instances why free trade should be encouraged in an economy. For his teachings on free trade, Adam Smith is often regarded as the world's first free-market capitalist. While that designation is probably a bit overstated, Smith's place in history as the father of modern economics and a major proponent of laissez-faire economic policies is quite secure. David Ricardo is another influential British economist of pro-free trade. He is well known for his neoclassical idea of the law of diminishing returns which appeared in his second major work in economics, (Formaini, 2012). He demonstrated his faith on free trade when he opposed the Corn 
Laws in Britain irrespective of the fact that himself was a land owner and profited from the laws. The Corn Laws, passed in 1815, forbade the importation into England of food grown elsewhere and sought to maintain the rising prices for British agricultural products that had occurred during the Napoleonic wars. Twenty-three years after Ricardo's death, the Corn Laws were repealed and Ricardo's international free trade agenda became one with British public policy.

One of the ideas for which Ricardo is most remembered is the theory of comparative advantage. He demonstrated using the theory, that "for two nations without input factor mobility, specialisation and trade could result in increased total output and lower costs than if each nation tried to produce in isolation." Ricardo further depicted using the theory that "nations will export not only what they have an absolute advantage in producing, but also what they have a comparative cost edge in producing." This assertion depicts Ricardo's furtherance of the belief in division of labour in international trade. A nation cannot be "Jack of all trade" because they will end up mastering none. Therefore, Ricardo advices that a nation should focus on the product which they have the means of producing in commercial quantity and which have export value. Ricardo's ideas reportedly became "the fountainhead of all nineteenth-century free trade doctrine."

Another British economist of free trade extraction, whose ideas, in fact allayed the fears of indigenous producers was John Stuart Mill. Mill (Blaug, 1986) was born into English liberalism. His father James was reportedly an ardent believer of laissez faire. Mill's belief in the freedom of the individual extended into his economic philosophy. His early economic philosophy was one of free market. However, with time he advocated for limited intervention and even leaned towards socialism. Mill was of the view that protecting duties on importation can be defensible when "imposed temporarily (especially in a young and rising nation) in hopes of naturalizing a foreign industry, in itself perfectly suitable to the circumstances of the country." But for him (Mill) these duties should be temporary and will be discontinued when the domestic infant industries have come of age. Other economists that emerged to 
support Mill's theory on infant industries were Alfred Marshall and Frank Taussig.

At this juncture, it will be pertinent to have a cursory look at the arguments of the earlier economists who were against free trade and favoured protectionism. Jean-Baptiste Colbert was one of such economists. Colbert's actions as the Controller General of Finance in France in 1665 depicted a strong advocacy for economic protectionism. In his bid to reconstruct the French economy, which was hitherto in chaos, he set out to protect the national industry by introducing tariffs against foreign produce, and then other countries replied with tariffs against French goods. This tariff warfare was one of the chief causes of the Dutch War of 1672 - 78. His short-comings notwithstanding, Colbert attracted the admiration of a lot of protectionists among them was the first United States Secretary of the Treasury Alexander Hamilton.

Alexander Hamilton used his position as the Secretary of the Treasury to author the economic policies of the George Washington administration; especially the funding of the state debts by the federal government, the establishment of a national bank, a system of tariffs, and friendly trade relations with Britain. Hamilton was reputedly harsh on the idea of free trade. In fact he was a nationalist who emphasized and encouraged strong central government and argued that implied powers of the Constitution be used to fund the national debt, assume state debts and create the government-owned Bank of the United States. These programs were funded primarily by a tariff on imports. Hamilton, therefore favoured the solidification of the domestic industries at the expense of foreign trade. He was one of the early Western advocates of import substitution. In his report on manufactures to the United States House of Representatives (referred to as Congress today) in 1791, Hamilton explained the futility of free trade with Europe and its possible adverse effect on manufacture when he wrote:

..., the United States cannot exchange with Europe on equal terms; and the want of reciprocity would render them the victim of a system, which should induce them to confine their views to Agriculture and refrain from Manufactures. A constant and 
increasing, on their part, for the commodities of Europe, and only a partial and occasional demand for their own, in return, could not but expose them to a state of impoverishment, compared with the opulence to which their political and natural advantages authorize them to aspire. ("Wikipedia Alexander Hamilton" Wikipedia online Encyclopaedia, accessed Sept. 3, 2014, http://www.wikipedia.com/intl/en/Alexander Hamilton. html)

Nonetheless, in the report, he praised the U.S trade measures which he claimed "accelerated internal improvements, which upon the whole have bettered our affairs." Hamilton proffered a rather aggressive stance in the trade relations between the U.S and Europe. He depicted this stance in his report when he further wrote "if Europe will not take from us the products of our soil, upon terms consistent with our interest, the natural remedy is to contract as fast as possible our wants of her."

Even though he admired the British system, Alexander Hamilton opposed the British ideas of free trade. He argued that free trade skewed benefits to colonial and imperial powers. He further contended that U.S protectionism would help develop the fledgling nation's emerging economy. Hamilton is considered to firmly support government intervention in favour of business. He drew from Adam Smith but opposed his laissez faire. His economic philosophy toed that of JeanBaptiste Colbert of France and he influenced economists such as Henry C. Carey and Friedrich List a German-American. Friedrich List was one of the economists who garnered inspiration from Alexander Hamilton's works which made him an economist of his pronounced "National System" views. He was strongly opposed to free trade and doubted the sincerity of Britain's on the subject. He questioned why a nation which achieved development by means of protective measures will, all of a sudden, decide to throw away these ladders of greatness and preach free trade to other nations and even go as far as declaring that she has hitherto wandered in the paths of error.

List passionately opposed Adam Smith. He accused Smith of instilling in the British the false sense of superiority. He also inferred that the British 
free trade advocacy was only a tool for imperialism. Establishing what may be the launching pad for African and other developing economies to attack the metropolitan imperialists, List stated that of the two countries maintaining free trade between one another, that one would be supreme which sold manufacturing goods, while that one would be subservient which could only sell agricultural produce. From the above position of List's it is obvious that many economists and scholars of the global South were inspired by his works and philosophy.

\section{Contemporary Free Trade Debate and the Position of the South in International Trade}

In the last section, the paper conducted a brief examination of a select scholars' position on free trade in the $18^{\text {th }}$ and $19^{\text {th }}$ centuries. The increasingly globalizing world has further intensified this debate. While many scholars believe that free trade remains a means through which global prosperity can be achieved, others debunk this trend only as a means of further impoverishing the global South by the North.

\section{Arguments for Free Trade}

The advocates of free trade in the $18^{\text {th }}$ and $19^{\text {th }}$ centuries rarely championed the cause for the reason of increasing material wealth. They believed it was morally right and that increased commerce would improve the international society. However, scholars of later decades started emphasising the material gains accruable from free trade. Jacob Viner showed that a trading bloc mutually lowering tariffs would produce gains not merely on the demand side but also on the supply side. This was referred to as "trade creation", the benefits to the supply side as a whole accrue as resources are re-allocated towards firms producing at the highest comparative advantage (among the partners) in each country. This, by extension, encourages innovation and export trade as exporters are empowered by the incentives from the international trade.

As the $20^{\text {th }}$ century progressed, economists became more interested in the material wealth made possible by free trade. The contemporary argument is that: 
...free trade can do wonders for a country's economy through improved allocation of resources in line with social marginal costs and benefits; access to better technologies, inputs and intermediate goods; economies of size and scale; greater domestic competition; availability of favorable growth externalities, like the transfer of know-how; and a shakeup of industry that may create an environment conducive to growth and development.( "Wikipedia Free Trade Debate" Wikipedia online Encyclopaedia, accessed Sept. 3, 2014, http://www.wikipedia.com/intl/en/Free Trade Debate. html)

One of the strong arguments of the contemporary proponents of free trade is the benefits of globalization. As highlighted above, free trade encourages transfer of technology and other know-hows. Globalisation itself came to be a term in international political economy because of the sustained encouragement of free trade. By globalizing, the world became more integrated, leading to a global economy and, increasingly, global economic policymaking, for example, through international agencies such as the World Trade Organisation (WTO). Palmer and Perkins (2007) declare that the economic interdependence of states is one of the basic conditions of international life.

They further present Eulenburg's argument that "no country is now economically independent; in the long run it needs trade with the rest of the world in order to survive". They back up their argument by asserting that some countries will dwindle away in penury if cut off from the aid that comes from the outside world, while some others will be impoverished if they cannot export their endowments. Nonetheless, scholars of the already impoverished global South are quick to brush aside such claims of "aid" as it is obviously merely an implementation of the old stick-and-carrot policy. As free trade takes the centre stage in international political economy, the debate became a moving dynamic encompassing such issues as labour provisions in bilateral and multilateral trade agreements. The scare of job insecurity and erosion of real wages of unskilled labour cause a sort of panic among the workers of developed countries. For example, in the North American Free Trade 
Agreement (NAFTA) zone, the common workers in the United States found themselves competing with cheap labour that flows in from Mexico. However, in a journal article, Robert L. Hetzel (1994) made a case for free trade in labour when he stated that "free trade allocates resources to their most efficient use. As part of this process, it redistributes jobs to the most productive industries, without affecting the total number of available jobs". On labour, the proponents of free trade further argued that free trade will be beneficial to developing countries since developing countries have abundant labour and they produce labour-intensive products, free trade will raise wage rates and increase income levels, which, in turn, will narrow the gap in income distribution within and among trading countries.

During financial crisis times, the advocates of economic protectionism develop strong arguments against free trade. But their arguments are debunked in some quarters based on the assertion that protectionism merely aggravates the recessionary forces and further push the economy into prolonged contraction. The proponents of free trade claim that it is free trade and free capital flows that will lift the world economy out of the doldrums. Finally, many advocates of free trade argue that globalization contributes to greater cooperation and less conflict; because the desire to achieve the "gains from trade" creates incentives for trading countries to maintain cooperative relations.

\section{Arguments against Free Trade}

In as much as the free trade advocacy enjoys wide acceptance from many scholars, the proponents of protectionism in trade equally have strong arguments to back their cause. Protectionism is normally advocated by anti-capitalist scholars who view the contact between the global North and South as based on unequal terms. An authority asserts that the debate on free trade is not whether there are gains from the practice because everyone agrees that free trade leads to net benefits to the trading partners. But the debate is over the distribution of these net gains because free trade also leads to winners and losers among trading partners. It was Friedrich List (Angirasa and Ocana, 2003) who drew the attention of the 
world to fact that a country could get locked into serving the needs of the world market in raw materials, and therefore not develop industrially. The developing world scholars and communists condemned this trend as evils of capitalism. V.I. Lenin internationalized Karl Marx's class structure. Lenin (1963) declares that "typical of the old capitalism, when free competition held undivided sway was the export of goods. The latest stage of capitalism, when monopolies rule, is the export of capital." What Lenin infers in the book was that the few capitalist countries - especially England - adopted free trade in order to keep supplying manufactured goods to the world and in exchange were to be constantly supplied with raw materials. Most of these raw materials came from the less developed countries and these trade relations were seen as inimical to these countries. Lenin presented a gloomy picture of sustained capitalism when he noted that:

As long as capitalism remains what it is, surplus capital will be utilized not for the purpose of raising the standard of living of the masses in a given country, for this would mean a decline in profits for the capitalist, but for the purpose of increasing profits by exporting capital abroad to the backward countries. (Lenin, 1963)

Decrying the practice of free trade during the early contact period between Africa and Europe, Walter Rodney (1973) laments that the developed and underdeveloped parts of the present capitalist section of the world have been in continuous contact four and half centuries (probably five centuries now considering the date of the publication) and over that period Africa helped to develop Western Europe in the same proportion as Western Europe helped to under-develop Africa. The advocates of the dependency theory, therefore, argues that poor countries exported primary commodities to the rich countries who then manufactured products out of these commodities and sold them back to the poorer countries because of the absence of protectionism.

Another strong argument of the protectionists is the idea of "infant industries". The idea was to improve the national industrial development before getting a free trade policy. Some argue that using protectionist 
measures to build up a huge industrial base in certain industries will then allow those sectors to dominate the world market.

A frightening effect of free trade and a point upon which those campaigning against free trade agreements like the NAFTA lay their point is that it reduces the low-skilled jobs, which are substituted with cheap labour from overseas. A case in point is the Mexican migrants who have largely taken over low-skilled jobs in the United States. Furthermore, free trade can result to excess dislocation as an employee may be open to seek employment in several fields over his lifetime. Still on its impacts on labour, the advocates of protectionism argue that that protection prevents wages from falling to the lower level of other countries. This is based on the assumption that protection is necessary to enable production to be carried out at the higher level of wages, and that if protectionism were withdrawn, production would decline on the account of home producers competing with foreign producers.

Then the major argument against free trade is the spread of economic recession and the depression that comes with it. This spread can come in different forms. The narrow specialty on a particular product encouraged by the theory of comparative advantage will adversely affect the country concerned in the event of a drop in demand of such good in the international market. Furthermore, multinational corporations (MNCs) with their subsidiaries across many countries may decide to shed their employees in these countries at the event of economic recession. Also a fall in stock in the mother country of a MNC may have a spillover effect on subsidiary countries which are mostly developing countries. Other arguments of the protectionists of the countries of the South include: free trade encourages capital flight; tax evasion by the MNCs; dumping ground syndrome; transfer of obsolete technologies; brain drain and so on.

\section{The Impact of the Free Trade and the Economic Recession of the $21^{\text {st }}$ Century on the South}

As free trade became an accepted norm in the international economic relations, global imbalances ensued. These imbalances took another form 
as the United States and some other developed economies began to experience significant balances of payments deficits. A report (Priewe, 2011) once stated that the United States deficit grew continuously from 1991, reaching a peak in 2006. This emerging global trend in trade has partly been traced to the cause of the economic recession of the $21^{\text {st }}$ century. The deficit suffered by the United States and some other developed countries has been as a result of financialisation and financeled capitalism. This is a process whereby there was less investment in fixed assets, deregulated financial markets - with stock prices as an efficient guide for corporate development - and the rise of investment banks and other non-banks. Unfortunately, globalization led many other economies to emulate the Wall Street model. An authority (Hall, 2013) states that "stock prices, rather than accumulation of fixed capital and technical progress, have been seen as heart peacemakers for the entire economy".

There was also increasing income inequality, weak wage increases in low - and middle - income households due to the effects of free trade on labour, falling propensity to save and increasing indebtedness in particular for house purchase. It was reported that in most OECD (Organization for Economic Co-operation and Development) countries the common feature is that growth of the real economy and employment has been weaker than in previous upswing phases of the business cycle. As a result, unsustainable macroeconomic regimes evolved which contributed to the emergence of the financial and economic crisis of the $21^{\text {st }}$ century. After building the United States economy on fragile foundation of the finance-led capitalism, the economy was shook to its foundation when in 2008 it was discovered that some of America's major banks, investment firms and stockbrokers had been selling questionable investments based on totally inflated real estate evaluations. When it came out that these inflated evaluations were in many instances based on dubious, even illegal practices, both the holders of these investment instruments and homeowners, saw their worth collapse. In the United States, this led to the closing of one of the major investment firms and the need for direct government intervention 
to investment houses and banks. As the depth of this crisis spread, so did its impact on other segments of the American economy. People were losing their houses and their jobs, unemployment began to rise, car sales drastically declined.

From all indications, the developing countries did not create the $21^{\text {st }}$ century financial and economic crisis but the effects are reverberating in some of the countries. The contagious nature of the economic crisis, made possible by free trade, was noted by the United Nations Commission on reforms of the International Financial System. It stated that "Many bilateral and multilateral trade agreements contain commitments that...may have exposed them unnecessarily to the contagion from failure elsewhere in the global economic system". This contagion was depicted when the financial crisis first hit the developed countries' banks. According to the IMF:

Unlike in developed economies, there has been no systemic banking crisis in Sub-Saharan Africa...However, as the crisis continues, risks could grow because parent banks could withdraw funds from subsidiaries and local banks. ("TWN Financial Crisis and Trade Agreements: Draft Preliminary Note", Third World Network, September, 2010, Accessed November 15, 2014, http://www.twnside.org.sg)

The Fund further explicated that risks of contagion from distressed foreign parent banks to local subsidiaries within Sub-Sahara Africa could be associated with parent banks (i)withdrawing capital from African subsidiaries; (ii)calling in loans to their African subsidiaries; (iii)no longer investing local profits in local subsidiaries or (iv)a combination of these considering that many financial institutions in Africa are foreignowned. Using India as an example, a study (Gupta, 2010) shows that some developing economies may not have experienced the financial meltdown and economic crisis the way they did if they were not actively integrated into the free trade activities with the developed countries. The study states that the primary reason for the greater impact of the crisis in India was India's increased integration with the rest of the world. There are evidences that show that India's industrial and trade cycles became 
increasingly correlated with those of the OECD countries over the past two decades. Moreover, while the share of trade in GDP increased from $23 \%$ in 1996-97 to close to $50 \%$ in $2007-08$, over the same period the ratio of gross capital flows to GDP more than tripled, from $17 \%$ to $56 \%$. Hence the global financial crisis was transmitted to India through both current and capital accounts.

In an attempt to directly blame this on capital flight, one will remember that the same IMF vehemently encouraged trade liberalisation which was part of their conditionality for loan. In what looked like a conspiracy to integrate developing economies into the global capitalism, the IMF "seal of approval" became a criterion to qualify for credit facilities from Western lending houses. Through the implementation of trade liberalisation, many developing countries signed numerous FTAs with the economies of the North and some of the provisions of these FTAs only serve to exacerbate the effects of the global economic recession of the $21^{\text {st }}$ century. A former Secretary-General of the United Nations Conference on Trade and Development (UNCTAD), actually observed that the developing countries were not technically prepared for the negotiations on free trade agreements while they lacked their own trade objectives and adequate strategies. He further opined that the developing countries were influenced, either ideologically or under pressure, by the dominant views of the time on the advantages of universal trade liberalisation.

One major handicap of the countries of the South in their free trade agreements with the North is the balance of payment crisis. There is generally low level of industrial capacity, especially in Africa, to diversify into manufacturing exports to balance the expenditure on imports. Because of this and many more reasons, the economic recession has had a severe impact on the developing economies.

One of the impacts is seen on the area of exchange rate. The financial sector was first hit by the crisis with several countries experiencing greater volatility in their exchange rates and stock markets. The currencies of six African countries were seen depreciating against the U.S dollar $30 \%$ or more between the third quarter of 2008 and the first 
quarter of 2009. This unanticipated movement in exchange rate has negative consequences for investment, output and growth of the developing economies.

The recession also affects the markets and bank balance sheets. Like every other country, the developing countries' local stock markets were severely affected by the crisis. Since the onset of the crisis there has been an increase in stock market volatility in the African region. It was reported that between the end of 2007 and January 22, 2010, the Nigerian stock exchange index declined by $62 \%$ and Egyptian and Kenyan exchange indices also declined by more than $30 \%$. Some of the changes in African stock exchange are shown in the table below.

Changes in African Stock Exchange Indices, 2007 - 2010. (Per cent)

\begin{tabular}{|c|c|c|c|}
\hline Country & Index & $\begin{array}{l}\text { End } 2007 \\
\text { to } \\
\text { end } 2008\end{array}$ & $\begin{array}{ll}\text { End } & 2007 \\
\text { to } & \\
22 & \text { Jan. } \\
2010 & \end{array}$ \\
\hline Ghana & $\begin{array}{l}\text { GSE All Share } \\
\text { Index }\end{array}$ & 58.1 & -17.0 \\
\hline Malawi & $\begin{array}{l}\text { Malawi All } \\
\text { Share Index }\end{array}$ & 25.6 & 6.3 \\
\hline $\begin{array}{l}\text { United Rep. of } \\
\text { Tanzania }\end{array}$ & DSEI & 21.3 & 16.3 \\
\hline Sudan & $\begin{array}{l}\text { Khartoum } \\
\text { index }\end{array}$ & -7.3 & \\
\hline Botswana & DCI & -16.5 & -13.3 \\
\hline Uganda & $\begin{array}{l}\text { USE All Share } \\
\text { Index }\end{array}$ & -21.4 & \\
\hline South Africa & $\begin{array}{l}\text { FTSE/JSE All } \\
\text { Share Index }\end{array}$ & -26.3 & -6.5 \\
\hline
\end{tabular}




\begin{tabular}{|l|l|l|l|}
\hline Zambia & $\begin{array}{l}\text { Lusaka All } \\
\text { Share Index }\end{array}$ & -29.1 & -27.0 \\
\hline Kenya & $\begin{array}{l}\text { NSE 20 Share } \\
\text { Index }\end{array}$ & -35.3 & -33.4 \\
\hline Mauritius & SEMDEX & -36.1 & -8.0 \\
\hline Namibia & $\begin{array}{l}\text { NSX Overall } \\
\text { Index }\end{array}$ & -40.1 & -18.9 \\
\hline Nigeria & $\begin{array}{l}\text { NSE All Share } \\
\text { Index }\end{array}$ & -45.8 & -62.0 \\
\hline Egypt & EGX 30 & -56.4 & -34.9 \\
\hline
\end{tabular}

Source: Patrick N. Osakwe, "Africa and the Global Financial and Economic Crisis: Impacts, Responses and Opportunities" in Sebastian Dullien et al (eds) The Financial and Economic Crisis of 2008-2009 and Developing Countries (New York: United Nations Publications),

The significant declines in net worth in stock markets increased the number of non-performing loans and caused deterioration in bank balance sheets in some countries.

The recession also affects trade and commodity prices in the developing economies. For example, Algeria's merchandise exports fell by about $53 \%$ in the third quarter of 2009 compared with the same quarter in 2008. Countries such as Burundi, Mauritius, Nigeria, South Africa and Tunisia also experienced significant reduction in merchandise exports over the same period. On the import side, Mauritius, Morocco, Nigeria, Sierra Leone, South Africa and Tunisia saw a more than $25 \%$ decline over that period. The slowdown in trade flows was due to declining import demand in key export markets, a shortage of trade finance and falling commodity prices. There was also the negative effect on capital flow. The developing economies mostly lack diversification and the crisis affected the demand for these products that form the bedrock of their economies thereby affecting capital flows. Furthermore, foreign direct investment (FDI) dwindled. In Africa, FDI flows declined by $36 \%$ 
in 2009. Reduced FDI flows had more severe impact in countries such as Gambia, Liberia, Chad, Equatorial Guinea, and Seychelles, that have average FDI-GDP ratios above $10 \%$.

The economic recession did not only affect the economic growth of the developing countries. The crisis also has socio-political implications. Foreign aid, which is important for a number of developing countries, diminished and this exacerbated the poverty situation already on ground. Also, there is fear that Western financial institutions and banks may demand for prompt repayment of debts to shore up their dwindling reserves. This and the general effects of the crisis lead to cut in health budget by some developing country governments. Their health budgets and resources have been constrained for many years already, so the crisis makes a bad situation worse.

In Latin America, much of the countries depend on trade with the United State (which absorbs half of Latin America's exports, alone). This situation is made possible via NAFTA and other agreements. The financial crisis that hit the United States has the spill over effect on these Latin American countries as their growth rate was slowed.

As the crisis rages on, countries raise trade barriers and economists have been questioning this strategy as an effective means to battle the meltdown.

\section{Conclusion}

The global economic recession of the $21^{\text {st }}$ century shows that mankind may not have learnt adequate lessons from history. The worst economic recession in modern history which led to the Great Depression of the 1930s shows the vulnerability of unregulated or ill-managed financial capitalism. The trend was allowed to develop again in the United States in the recent times and through free trade and globalisation it was easily spread across the world. The bankruptcy of the United States investment bank, Lehman Brothers, on 15 September 2008 was a milestone in the 2008 financial crisis. When the meltdown and the concomitant 
depression finally came, it also spread around the globe because of increasing trade liberalisation and bilateral and multilateral Free Trade Agreements (FTAs) supervised by the World Trade Organisation (WTO). While economies struggle with various recovery plans, the question becomes: how far can free trade be allowed to thrive to avoid the spread of economic recession? Secondly, how can developing countries raise their bargaining power when they are faced with trade liberalisation on unequal terms?

This work proposes that a measure of protectionism should be reserved in the area of infant industries to protect them from the harsh competition of foreign trade. By so doing, jobs will be saved and these industries will have breathing space to develop their capacity to face competition both at home and elsewhere. Nonetheless, care should be taken not to place stiff barriers that will hamper economic integration (especially among like economies), which is an ingredient of sustainable economic growth and development.

Even though it may be unfashionable to continue pointing at Europe as under-developing Africa at the present era, there is still need to reevaluate the trade relations between the North and the South. Emphasizing that free trade remains the ultimate aim of every nation once all economies have reached the same level of development; there is need for revision of international trade rules. In the design of the new rules more attention should be paid to the level of development and industrial capacity of developing countries. By so doing free trade will be more gainful and the effects of depression in an event of economic crisis may be ameliorated in these countries of the global South.

Nwachukwu J. Obiakor

\& Abuoma C. Agajelu

Department of History

and International Studies

Nnamdi Azikiwe University

Awka 


\section{References}

Ake, Claude (1981), A Political Economy of Africa (Essex: Longman Group,), 110.

Afesorgbor, Sylvanus Kwaku and Bergeijk, Peter A.G. van (2011), "Multi-Membership and the Effectiveness of Regional Trade Agreement in Western and Southern Africa. A Comparative Study of ECOWAS and SADC", International Institute of Social Studies (520):6.

Angirasa, Aditi K. and Ocana, Claudia (2003), "The Free Trade Debate: One More Round", (Paper Presented at the Southern Agricultural Economics Association Annual meeting, Mobile, Alabama), 2.

Blaug, Mark (1986), Great Economists before Keynes (New York: Cambridge University Press), 203.

Bobulescu, Roxana (2003) "Protectionism in Retrospect: Milhail

Manoilescu (1891-1950?)" Brazilian Journal of

Political Economy, 23(4): 114.

Cai, Jei and An, Lian (2014), "Is Protectionism Rational Under the Financial Crisis? Analysis from the perspective of International Political Relations", Asian Economic and Financial Review, 4(3): 279.

Driesen, David M. "What is Free Trade? The Real Issue Lurking Behind the Trade and Environment Debate," Social Science Research Network Electronic Paper Collection: Accessed August 10, 2014, http://papers.ssrn.com/paper.taf?abstract_id=217412

Eisenberg, Jeffrey "Dependency Theory: An Introduction", Accessed August 21, $2014 \quad$ http://www.worldconnected.org

"European Free Trade Association (EFTA)," Encyclopaedia Britannica,

Encyclopaedia Britannica Student and Home Edition, (Chicago:

Encyclopaedia Britannica, 2010).

Formaini, Robert L. (2012), "David Ricardo Theory of Free International Trade", Economic Insights: Federal Reserve Bank of Dallas 9(2): 1 . 
Freeman, Lawrence and Bowen, Marsha L. (2008), "The Legacy of Friedrich List: The American System's Battle Against British Free Trade", EIR The American Patriot: 56 - 57.

"Free Trade" Business Dictionary Online, Accessed August 10, 2014.

"Free Trade," Encyclopaedia Britannica, Encyclopaedia Britannica Student and Home Edition, (Chicago: Encyclopaedia Britannica, 2010).

"General Agreement on Tariff and Trade (GATT)," Encyclopaedia Britannica, Encyclopaedia Britannica Student and Home Edition, (Chicago: Encyclopaedia Britannica, 2010).

George, Henry (1949), Protection or Free Trade: An Examination of the Tariff Question, with Especial Regard to the Interests of Labor (New York: Robert Schalkenbach Foundation), 117.

Gupta, Abhijit Sen "Sustaining Growth in a Period of Global Downturn:

The Case of India" in The Financial and Economic Crisis of 2008-2009 and Developing Countries eds. Sebastian

Dullien et al (New York: United Nations Publications), 155.

Hall, John Whitney (2013) (ed), History of the World: Earliest Times to the Present Day(Massachusetts: World Publications Group, Inc.), $894-895$.

Hamilton, Alexander (1791), "Report on Manufactures", A Report Communicated to the House of Representatives on December 5, 1791, Assessed Sept 3, 2014 http://www.worldconnected.org, 7.

Heilbroner, Robert L. (2010) “Adam Smith,” Encyclopaedia Britannica, Encyclopaedia Britannica Student and Home Edition, (Chicago: Encyclopaedia Britannica).

Hetzel, Robert L. (1994), "The Free Trade Debate: The Illusion of Security Versus Growth", Federal Reserve Bank of Richmond Economic Quarterly (80): 39

"Investopedia Free Trade" Investopedia online Encyclopaedia, accessed August 10 , 2014 , http://www.investopedia.com/intl/en/Free Trade. html 
Irwin, Douglas A. (1990), "Free Trade at Risk?" International Finance Discussion Papers. (3): 2.

"Laissez-faire", Merriam-Webster's Dictionary and Thesaurus in Encyclopaedia Britannica Student and Home Edition, (Chicago: Encyclopaedia Britannica, 2010).

Lenin, V.I. (1963), Imperialism: The Highest Stage of Capitalism (Moscow: Progress Publishers,), 16.

Miller, Kenneth E. (1961), “John Stuart Mill's Theory of International Relations", Journal of History of Ideas 22(4): 493 - 514.

"North American Free Trade Agreement (NAFTA)," Encyclopaedia Britannica, Encyclopaedia Britannica Student and Home Edition, (Chicago: Encyclopaedia Britannica, 2010).

Osakwe, Patrick N. (2010), "Africa and the Global Financial and Economic Crisis: Impacts, Responses and Opportunities" in Dullien, Sebastian et al (eds) The Financial and Economic Crisis of 2008-2009 and Developing Countries (New York: United Nations Publications), 209.

Oyejide, T.A, et al (1985), Nigeria and the IMF (Ibadan: Heinemann Educational Books), 100.

Palmer, Norman D. and Perkins, Howard C. (2007), International Relations: The World Community in Transition (third revised edition), (Delhi: A.I.T.B.S. Publishers \& Distributors,), 139.

Prabhakar, Akhilesh Chandra (2010), "An Investigation of the Global Economic and Financial Crisis: A Review", African Journal of Marketing Management 2(3): 45.

Priewe, Jan (2010), "What Went Wrong? Alternative Interpretations of the Global Financial Crisis", in The Financial and Economic Crisis of 2008-2009 and Developing Countries eds. Dullien Sebastian et al (New York: United Nations Publications), 30. "Protectionism," Encyclopaedia Britannica, Encyclopaedia Britannica Student and Home Edition, (Chicago: Encyclopaedia Britannica, 2010). 
"Recession," Encyclopaedia Britannica, Encyclopaedia Britannica Student and Home Edition, (Chicago: Encyclopaedia Britannica, 2010).

Rodney, Walter, (1973), How Europe Underdeveloped Africa (London: Bogle-L'Ouverture publications, 116.

Shafaeddin, Mehdi (2000), "Free Trade or Fair Trade? An Enquiry into the Causes of Failure in Recent Trade Negotiations" United Nations Conference on Trade and Development, (153): 2 - 3.

Shah, Anup "Global Financial Crisis" Assessed Sept 3, 2014 http://www.globalissues.org/article/768/global-financial-crisis.

Shiskin, Julius "The Changing Business Cycle", New York Times, December 1, 1974, 38.

Smith, Adam (1976), An Inquiry into the Nature and Causes of the Wealth of Nations (Oxford: University Press), 244.

"South", Merriam-Webster's Dictionary and Thesaurus in Encyclopaedia Britannica Student and Home Edition, (Chicago: Encyclopaedia Britannica, 2010).

Stein, Leslie (1979), "Dependency Theories and Underdevelopment", Journal of Economic Studies (6) :2.

Tapié, Victor-Lucien (2010), "Colbert Jean-Baptiste”, Encyclopaedia Britannica, Encyclopaedia Britannica Student and Home Edition, (Chicago: Encyclopaedia Britannica).

Todaro, Michael P. and Smith, Stephen C. (2011), Economic Development: eleventh edition (Essex: Pearson), 128.

"TWN Financial Crisis and Trade Agreements: Draft Preliminary Note", Third World Network, September, 2010, Accessed November 15, 2014, http://www.twnside.org.sg

Vivo, G. de (1987), "David Ricardo", in The New Palgrave: A Dictionary of Economics, eds Eatwell, John et al. (London: Macmillan Press,), 98.

"Wikipedia Free Trade" Wikipedia online Encyclopaedia, accessed August 10, 2014, http://www.wikipedia.com/intl/en/Free

Trade. html 
"Wikipedia Alexander Hamilton" Wikipedia online Encyclopaedia, accessed Sept. 3, 2014, http://www.wikipedia.com/intl/en/Alexander Hamilton. html

"Wikipedia Free Trade Debate" Wikipedia online Encyclopaedia, accessed Sept. 3, 2014, http://www.wikipedia.com/int1/en/Free Trade Debate. html

"Wikipedia Friedrich List" Wikipedia online Encyclopaedia, accessed Sept. 3, 2014, http://www.wikipedia.com/intl/en/Friedrich List. html

"Wikipedia John Stuart Mill" Wikipedia online Encyclopaedia, accessed Sept. 3, 2014, http://www.wikipedia.com/intl/en/John Stuart Mill. html

"Wikipedia Recession" Wikipedia online Encyclopaedia, accessed August 10, 2014, http://www.wikipedia.com/intl/en/Recession. html

Wonnacott, Paul (2010), "International Trade," Encyclopaedia Britannica, Encyclopaedia Britannica Student and Home Edition, (Chicago: Encyclopaedia Britannica). 